\section{THE EUROPEAN COLONIES AND THEIR TRADE.}

THE large commerce between Great Britain and her colonies has, especially within' the last ten or fifteen years, attracted the attention of the other European countries. They have watched with covetous eyes its steady increase and the rapid growth of the English mercantile marine, and have studied the policy which has either made the colonies of England self-supporting, or, where the expenses exceeded the revenues, pay tribute to London bankers in the form of interest at high rates on colonial loans.

Attempting to follow England's example, France and Germany have founded colonies, hoping to realize from them large commercial returns. Instead of this, the commerce with the colonies they have established has been very limited, and the outlays involved have imposed a heavy burden upon the home treasury. Even Algiers, the most prosperous of the colonies established by France, has been a constant and increasing expense. The attempt to establish a French colony in Madagascar has been abandoned, while that in Tonquin has only been maintained by the constant presence of a large army. The war with China, in which France became involved through the attempt to establish this colony, has caused a great drain on France, both of men and money; and, even at the present time, there is such a constant turmoil in northern Tonquin, that further demands of credit and fresh drafts of soldiers must constantly be made. This state of affairs will probably cause the overthrow of the ministry, if not of the republic; and the ministry have sought to avert their fate by sending M. Bert, a former minister of instruction, as governor, with full power in civil and military matters. It is asserted, and the facts seem to corroborate the statement, that the expense of maintaining the colonies of France, including the support of the required armies, largely exceeds the total value of the commerce, including both imports and exports; that the death-rate is in excess of the births; and that the French population is only maintained by draining France of her most enterprising citizens. These facts have become so overwhelming, that a party has recently been formed in France, advocating the abandonment of all her foreign possessions.

Germany recently took possession of an exten- sive territory on the south-western coast of Africa ; but a rainless climate and a barren soil have proved insurmountable obstacles even to German thrift. Another German colony has been established on the east coast, west of Zanzibar, between the second and fifth degrees of north latitude, extending westerly into the interior. Several large rivers flow through this territory, rising in the mountain-range which separates the ocean from Lake Tanganyika. In the upland country the climate is probably healthy, and the soil rich. The Germans have also a small colony at Cameroon, on the west coast, under the equator ; but here the natives have opposed the settlers, and their progress consequently has been slow. Of the commerce of German colonies, however, nothing is known, as no official returns have been published.

Italy has recently established a colony at Massowah, upon the Red Sea, with the result, thus far, of an increased deficit in the treasury. The Netherlands retains a part of its possessions in Asia; Spain and Portugal, a portion of the immense territory they formerly held in Africa and in America; and Denmark, her hold upon Greenland, Iceland, and three islands in the West Indies. The cost of maintaining these domains exceeds the revenue; but the deficit is small, and fully compensated by the commercial advantages derived from them. Belgium and Austria, on the other hand, have no foreign possessions. The Kongo Free States, which had their origin in Belgium, are a private enterprise of King Leopold II., and have been supported from his private purse. The cost of their maintenance has hitherto been very heavy, and must continue to increase, until the railroad around the falls between Vivi and Stanley Pool is constructed, allowing of the creation of trade with central Africa, and the consequent tax levies to defray the expenses of the undertaking.

Russia can hardly be said to have any colonies. The vast regions in Asia which have been settled by her people, willingly or unwillingly, should be looked upon as but natural expansions of her dominions; and little is known, either of their cost to the state, or the extent of their commerce.

Austro-Hungary alone, of the European countries, remains to be considered, and that kingdom is little more than a congery of colonies. Eleven different languages are spoken within its borders, and the people of this heterogeneous empire have 
no desire to colonize other regions than those taken from Turkey.

The following tables are of much interest. They show that eighty per cent of the colonial territory held by Europe belongs to Great Britain, that over eighty per cent of the entire commerce is with Great Britain, while the territory of its colonies is sixty times as large as that of Great Britain itself.

\section{Territory.}

\begin{tabular}{|c|c|c|c|c|c|}
\hline \multirow{2}{*}{ Countries. } & \multicolumn{3}{|c|}{ Surface in square kilometres. } & \multicolumn{2}{|c|}{$\begin{array}{c}\text { Per. } \\
\text { centages. }\end{array}$} \\
\hline & $\begin{array}{l}\text { Mother- } \\
\text { country. }\end{array}$ & Colonies. & Total. & $\begin{array}{l}\text { Moth. } \\
\text { coun. }\end{array}$ & Col's. \\
\hline Eng & 312,639 & $20,552,574$ & $20,865,213$ & 1.5 & 98.5 \\
\hline Port & 89,297 & $1,82 \tau, 259$ & $1,916,556$ & 4.7 & 95.3 \\
\hline Netherl'ds. & 32,745 & $1,76 \tau, 748$ & $1,800,493$ & 1.8 & 98.2 \\
\hline e... & 528,393 & 990,825 & $1,519,218$ & 34.8 & $65 \cdot 2$ \\
\hline Spq & 499,570 & 429,085 & 928,655 & 53.3 & 46.2 \\
\hline Denmar & 35,686 & 225.564 & 261,250 & 13.7 & 86.3 \\
\hline Total & $1,498,330$ & $25,793,055$ & $27,291,385$ & 5.5 & 94.5 \\
\hline
\end{tabular}

Population.

\begin{tabular}{|c|c|c|c|c|c|}
\hline \multirow{2}{*}{ Countries. } & \multicolumn{3}{|c|}{ Population in 1881.} & \multicolumn{2}{|c|}{$\begin{array}{c}\text { Per- } \\
\text { centages. }\end{array}$} \\
\hline & $\begin{array}{l}\text { Mother- } \\
\text { country. }\end{array}$ & Colonies. & Total. & $\begin{array}{l}\text { Moth. } \\
\text { coun. }\end{array}$ & Col's. \\
\hline Englan & $35,153,780$ & $213,918,000$ & $249,0 \curlyvee 1,000$ & 14.1 & 85.9 \\
\hline Net & $4,172.991$ & 26,8 & 31 , & 13.5 & 86.5 \\
\hline France.... & $37,672,048$ & $8,722,857$ & $46,394,905$ & 81.2 & 18.9 \\
\hline Spain....... & $16,350,8 \pi 4$ & $8,175,467$ & $24,526.341$ & 66.7 & 33.3 \\
\hline Portugal... & $4,160,315$ & $3,723,967$ & & 52.8 & 47.2 \\
\hline Denmark.. & $1,969,045$ & 127,122 & $2,096,167$ & 91.8 & 8.2 \\
\hline Total. & $99,479,053$ & $261,509,010$ & $360,988,063$ & 27.6 & 72.4 \\
\hline
\end{tabular}

Trade.

\begin{tabular}{|c|c|c|c|}
\hline Countries. & $\begin{array}{c}\text { Commerce } \\
\text { of the } \\
\text { mother-coun- } \\
\text { try. }\end{array}$ & $\begin{array}{c}\text { Commerce of } \\
\text { the colonies } \\
\text { with the } \\
\text { moth.-country. }\end{array}$ & 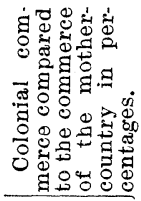 \\
\hline $\begin{array}{l}\text { England ....... } \\
\text { France ........ } \\
\text { Netherlands... } \\
\text { Spain.... .... } \\
\text { Denmark ..... } \\
\text { Portugal ..... }\end{array}$ & $\begin{array}{r}17,884,275,000 \\
10,636,300,000 \\
4,428,450,000 \\
1,371,150,000 \\
598,950000 \\
391,950,000\end{array}$ & $\begin{array}{r}4,658,950,000 \\
526,400,000 \\
200,200,000 \\
128,800,000 \\
22,500,000 \\
\tau, 925,000\end{array}$ & $\begin{array}{r}26.00 \\
4.95 \\
4.50 \\
9.39 \\
2.46 \\
2.02\end{array}$ \\
\hline Tota & $35,311,275,000$ & $5,544,775,000$ & $15 . \hat{0}$ \\
\hline
\end{tabular}

Gardiner G. HubBard.

\section{THE U. S. GEOLOGICAL SURVEY.}

As a part of the evidence before the commission considering the organization of the government scientific bureaus, there was recently presented a letter from $\mathrm{Mr}$. Alexander Agassiz, in which he took occasion to censure the work of the geological survey, and to condemn to some extent its existence as a government institution.

One question raised by Mr. Agassiz is whether the work carried on by the survey should not be left to individual enterprise. In answer to this, Major Powell, in a reply addressed to the commission, calls attention to the large expenditures required for such work, and adds, that he has no knowledge of any case where private institutions, such as colleges or societies, have undertaken to do field-work in topography and geology. To some extent individuals, notably a few college professors, have made geological excursions in the field, and have accumulated valuable material.

The principal publications in this country on geology and paleontology, however, have contained the results of investigations carried on at the expense of the general or state governments ; and the publication of such results, on account of the cost of the plates required, is far beyond the resources of private institutions. To show the relation between the official publications and those at private expense, Major Powell presents some figures collected from the material in the library of the geological survey. They do not represent the entire body of publication, but it is believed that they fairly give the ratio of official to private matter. These figures show 105, 795 pages on general geology published by the government, to 15,139 pages published by private parties. The ratio of geological maps is about the same; and, comparing the amount of governmental with the amount of private publications in paleontology, the ratio of number of pages is 18,151 to 13,916 ; the number of plates being as 2,858 to 769 .

The publications of the survey contain the writings of nearly all our best geologists; and it is thought by Major Powell that a wide distribution of its scientific reports, placing them at the disposal of one or two libraries in each county in the country, would tend to make the results of the investigations as available as they should be.

It has been especially fortunate for the survey that there 6 xists in the Comstock, Eureka, and Leadville mining districts vast shafts and galleries which have allowed of an unparalleled study of problems in economic geology ; and great credit is due to the survey for having taken advantage of these opportunities. As the law establishing the 